\title{
Improving Accreditation of Higher Education in Vietnam in the Integration Process
}

\author{
Nguyen Quang Giao, Ph.D. \\ The University of Danang, Vietnam
}

\begin{abstract}
Globalization has a strong impact on the development of economic, society and education of all countries in the world. In this context, the issue of quality education, quality assurance and accreditation of education has become common for institutions of higher education. Accreditation of higher education in Vietnam began to be implemented with the establishment of the Department of Testing and Accreditation in 2003 and especially the issuance of the Education Act (2005) which stated: "Accreditation is performed periodically in nationwide and for each institution. The result of accreditation of education is announced publicly to society known and monitoring". Accreditation of higher education in Vietnam after about 10 years implemented has achieved important results such as the accreditation system of higher education has been formed; the legal documents system of accreditation is increasingly perfected; accreditation of higher education received the attention of the members of the universities and society... However, there are some restrictions of accreditation of higher education in Vietnam such as use of result of accreditation of education, number of accreditors and funds for accreditation of education are limited... In the context of regional and international integration, accreditation of higher education in Vietnam faces many difficulties and challenges in condition of accreditation of higher education in Vietnam is relatively new issue compared to other countries in the region and the world. Improving accreditation of higher education to meet the requirements of the integration process is an important task for higher education in Vietnam today. The article refers to the basic content of the accreditation of higher education, accreditation of higher education situation in Vietnam and proposes measures to improve accreditation of higher education in Vietnam in the integration process.
\end{abstract}

Keywords: accreditation, self-assessment, external assessment, higher education, quality

\section{Introduction}

Accreditation of higher education needed in most countries because the result of accreditation of education will reflect the quality of universities and training programs. This is an important information channel connected between the academic community and society. Especifically, for students, result of accreditation of education can ensure the program students learn are under control and meet the training standards of the national career, as well as achieve the goal set by the universities. For teachers, accreditation of education provides information to improve the program and the recognition of the scientific achievements attained. For researchers of education, accreditation of education will provide a forum for educators; researchers can exchange ideas and future directions in training. For society, accreditation of education ensures a program or an institution of education has achieved the compatible with the objectives stated previously. Therefore, most nations in the world are interested in implementing accreditation of education in general and accreditation of higher education in particular.

In recent years, accreditation of higher education in Vietnam has been implemented and achieved positive results to contribute in improving the quality of education. However accreditation of higher education in Vietnam after nearly 10 years implemented has certain limitations. The process of regional and international integration requires accreditation of higher education in Vietnam to be improved and perfected to meet the regional and international quality standards of education.

\section{The concept of accreditation of higher education in Vietnam}

Accreditation is derived from the United States and North America. Grilo (2003) argued that accreditation was a system of external quality assurance which had several decades in the United States of America and had its origin in an external evaluation.

The International Network for Quality Assurance Agencies in Higher Education (INQAAHE) is a world-wide association of over 200 organizations active in the theory and practice of quality assurance in higher education. Most of the countries around the world participating in the INQAAHE are implementing accreditation in higher education to continuously improve the quality of education (website: http://www.inqaahe.org).

According to the Council for Higher Education Accreditation, accreditation in higher education is defined as a collegial process based on self and peer assessment for public accountability and improvement of academic quality. Peers assess the quality of an institution or academic program and assist the faculty and staff in improvement".

David D. Dill, William F. Massy, Peter R. Williama and Charles M. Cook (1996) argued that the accreditation process determines whether an institution or a program meets threshold quality criteria and therefore certifies to the public the existence of minimum educational standards". Besides, accreditation is the procedure for formal recognition of a higher education institution or study program that it delivers by the external body, carried out on the basis of external quality assessment verifying thereby that specific standards 


\section{International Journal of Science and Research (IJSR) \\ ISSN (Online): 2319-7064}

Index Copernicus Value (2013): 6.14 | Impact Factor (2014): 5.611

and criteria have been met"

(http://www.cep.edu.rs/sites/default/files/Higher Education Accreditation In procedure.pdf.).

Sanyal and Martin (2007) argued that accreditation is the outcome of a process by which a governmental, parastatal or private body (accreditation agency) evaluates the quality of a higher education institution as a whole, or a specific higher education program/course, in order to formally recognize it as having met certain predetermined criteria or standards and award a quality label".

As with other quality assurance mechanisms, accreditation is meant to ensure social accountability, academic improvement, institutional performance efficiency and effectiveness, value for money, and consumer protection (Singh, 2010). Singh further notes that accreditation less commonly deals with values, such as social purposes like equity, social justice, and democracy.

Lazăr VLĂSCEANU, Laura GRÜNBERG and Dan PÂRLEA (2007) argued that accreditation is the process by which a (non) governmental or private body evaluates the quality of a higher education institution as a whole or of a specific educational program in order to formally recognize it as having met certain predetermined minimal criteria or standards. The result of this process is usually the awarding of a status (a yes/no decision), of recognition, and sometimes of a license to operate within a time limited validity. The process can imply initial and periodic self study and evaluation by external peers. The accreditation process generally involves three specific steps: (i) a self evaluation process conducted by the faculty, the administrators, and the staff of the institution or academic program, resulting in a report that takes as its reference the set of standards and criteria of the accrediting body; (ii) a study visit, conducted by a team of peers, selected by the accrediting organization, which reviews the evidence, visits the premises, and interviews the academic and administrative staff, resulting in an assessment report, including a recommendation to the commission of the accrediting body; (iii) an examination by the commission of the evidence and judgment and the communication of the formal decision to the institution and other constituencies, if appropriate".

Accreditation of education is quite different in countries. In some countries there is institutional accreditation, some others only program accreditation, but also the simultaneous use of both institutional accreditation and program accreditation.

In Vietnam, accreditation of higher education includes: Institutional accreditation and program accreditation. According to the regulation No 62/2012/TT-BGDĐT on procedures and cycle of accreditation of universities, colleges and professional secondary schools promulgated by the MOET (2012), institutional accreditation is assessment and recognition the quality level institution meets the objective, content and curriculum. In 2013, the MOET promulgated the regulation No 38/2013/TT-BGDĐT on procedures and cycle of program accreditation of universities, colleges and professional secondary, in which program accreditation is assessment and recognition the quality level of program meets standards of quality assessment by MOET.

Accreditation of higher education in Vietnam must ensure the following principles: (a) Independent, objective and lawful; (b) Honesty, openness and transparent; (c) Equal, mandatory, periodic. According to the regulation of MOET, all universities, colleges and professional secondary schools in Vietnam must be accredited by accrediting agency.

The process of accreditation of higher education in Vietnam includes the followings: (1) educational institution conducts self-assessment; (2) educational institution registers with accreditation organization and suggested consideration recognized quality standards of education; (3) accreditation organization conducts the external review; (4) accreditation organization appraises, recognizes or denies attained standards of quality education of educational institution.

According to the regulation No 62/2012/TT-BGDĐT promulgated by the MOET (2012) on procedures and cycle of accreditation of universities, colleges and professional secondary schools, -self assessment is the process which education institution self consider, research based on the criteria of quality education by the Ministry of Education and Training issued to report on the state of education quality, efficiency of training, scientific research, human resources, facilities and other issues related in order to educational institution adjusts the resources and processes implemented to achieve the quality standards of education" and -external assessment is the process of surveying and evaluation of accrediting agency based on the quality standards of education issued by the MOET to determine institution's level to meet quality standards of education". Accreditation of higher education in Vietnam is conducted every five years.

Self-assessment is the first step in the process of accreditation of higher education and plays an important role to help universities determine the actual quality in order to apply measures to improve and enhance the quality of teaching and learning. Through self-assessment, based on the analysis of evidence and comparison to criteria of quality standards of education, the universities self-review, inspect, identify strengths and weaknesses to design feasible plans to improve quality of education and apply measures to meet the quality standards of education. Besides, the self -assessment process also represents autonomy and accountability of universities in research activities and social services according to the mission and function. In addition, implementing selfassessment report requires university's members to participate, so awareness and self-discipline of all members are enhanced through the process of implementing selfassessment report. Moreover, the recognition result is the basis for universities to publicly inform the community about their actual quality of education of units.

According to Council for Higher Education Accreditation (2010), for students, accreditation provides value related to not only judging quality, but also obtaining employment, receiving student aid and transferring credits. Accreditation of higher education encourages confidence that the educational activities of an accredited institution or program have been found to be satisfactory; assists with student

\section{Volume 5 Issue 3, March 2016}




\section{International Journal of Science and Research (IJSR) \\ ISSN (Online): 2319-7064 \\ Index Copernicus Value (2013): 6.14 | Impact Factor (2014): 5.611}

mobility; signals to prospective employers that a student's educational program has widely met the accepted standards, with graduation from an accredited program, in some cases, as a prerequisite for entering a profession; provides access to federal and sometimes state financial aid, available to qualified students who attend institutions accredited by recognized accrediting organizations. Besides publishing the recognition, the accreditation process provides findings through judging quality, assures reliable information about the quality of institutions or programs, promotes accountability of universities as well as identifies successful improvement efforts. Accreditation confirms that the public presentation of an educational program, student services and graduate accomplishments is fair and accurate; promotes accountability through ongoing external evaluation of the institution or program, with a finding that there is compliance with general expectations in higher education or a professional field as reflected in the accreditation standards; identifies institutions and programs that have voluntarily undertaken explicit activities directed at improving the quality of the institution and its professional programs and are carrying them out successfully.

Accreditation of higher education in Vietnam contributes to ensure and improve the quality of education. The result of accreditation confirms the institution's quality level meets its objectives in certain periods; is the basis for the institution to explain to the state agency and social about situation of the quality of education and is a basis for learner to select an educational institution and for employers to recruit human resource. All universities in Vietnam conduct accreditation of higher education.

\section{Accreditation of higher education in Vietnam in the integration process}

Accreditation of higher education in Vietnam has been deployed for over 10 years. In early 2002, the MOET established Quality Control Division. In 2003, the establishment of Department of Testing and Accreditation has marked a new stage of development of the accreditation system of education in Vietnam. In 2004, the Ministry of Education and Training issued the temporary regulations on accreditation of universities as a tool to implement accreditation activities in the country. To date, the MOET has issued a full range of legal documents for implementing accreditation of higher education and these are being implemented. Besides, MOET established the National Council for Accreditation of Education with the task of assessing accrediting agencies of education, counseling, assisting the Minister of MOET in the establishment, licensing accrediting agencies. National Council for Accreditation of Education is independent of the MOET in professional activities.

Since 2005, the universities in Vietnam have been trained to implement self-assessment by MOET and have done selfassessment reports. In January 2016, 553 universities, colleges and vocational schools in Vietnam completed the self-assessment report (http://www.moet.gov.vn/). But so far only 60 universities have been externally assessed by the team of accreditors established by MOET. This is one of the big challenges for higher education in Vietnam.

In 2013, MOET established two accreditation centers at the National University Hanoi and the National University of Ho Chi Minh City. This marks accreditation of higher education in Vietnam become independent in the external assessment process.

The accrediting agency of education around the world is quite diverse in terms of ownership (of the State, associations or organizations, other individuals), the subjects accredited (institution, program, all levels of education and only higher education,...), dependent or independent of the state (fully independent of state, independent in making professional decisions but still receiving state funding and depend entirely on the state),...

In Vietnam, the accrediting agency of higher education is a specialized unit, can be an agency, office, center or company, and has legal personality. The accrediting agency of higher education has the Council for Accreditation of Education established by the agency's leaders and has a team of experts of accreditation to deploy activities of education accreditation. The accrediting agency of higher education is independence in deciding to recognize or not recognize the level of an educational institution according to the quality standards of education.

According to the of construction and development accreditation system of higher education and professional secondary school in period 2011 - 2020, accreditation system of higher education in Vietnam includes:

- The State Administration for accreditation of education is MOET.

- The accrediting agency of education includes:

+ Accrediting agency is established by the state is the organization accreditation of higher education and professional secondary schools established by the MOET and periodically is granted license to accredit public and private educational institutions and programs of higher education and vocational schools.

+ Accrediting agencies is established by private organizations and individuals include:

* Organizational and professional bodies wish to establish accreditation organization and have permission of establishing by the Minister of Education and Training and periodically is granted license to accredit in the specific field. * Individual wishes to establish accreditation organization and have permission establishing by the Minister of Education and Training and periodically is gotten license to accredit in the specific field. 


\section{International Journal of Science and Research (IJSR) \\ ISSN (Online): 2319-7064}

Index Copernicus Value (2013): 6.14 | Impact Factor (2014): 5.611

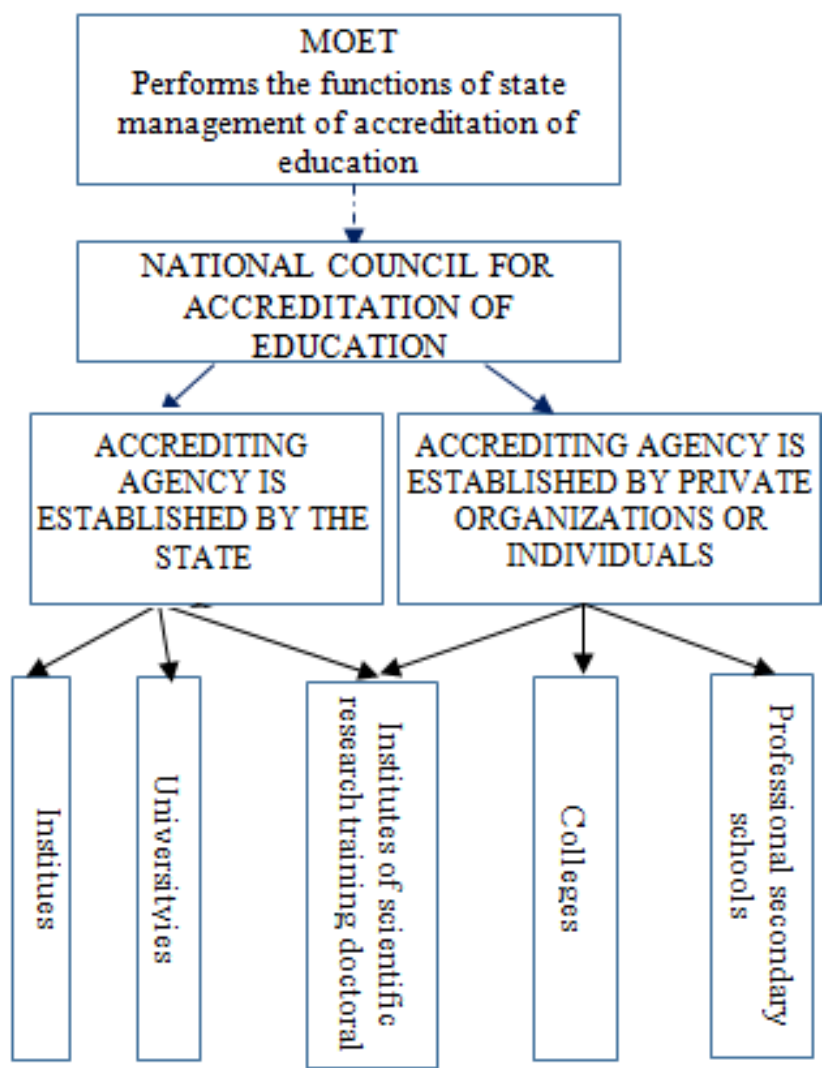

Figure 1: Accreditation system of higher education in Vietnam

Up to now most universities in Vietnam implement selfassessment reports and apply multiple measures to improve internal quality of education to meet quality standards of education issued by MOET. Actually, accreditation of higher education in Vietnam always attracts interest and direction, favorable conditions of university leaders. Through participating in accreditation of higher education, awareness of the management staff, faculty and students of accreditation of higher education in general and self assessment in accreditation of higher education in particular are enhanced. Moreover, participating in accreditation of higher education has practical contributions in improving quality of education of universities.

However, according to assessment of the project of construction and development accreditation system of higher education and professional secondary school in period 2011 - 2020, accreditation system of higher education in Vietnam still has some limitations, for example, it neither really keeps up with requirements of social- economic development of the country nor approach the level of the regional and international advanced countries".

Higher education in Vietnam is in the process of the regional and international integration especially in ASEAN community; accreditation of higher education in Vietnam has to face difficulties and challenges. Firstly, it's international cooperation in accreditation of higher education. Although Vietnam has been involved in the organization of quality assurance and accreditation in the world, the role of Vietnam is limited because the accreditation of higher education is a quite new issue in Vietnam. The number of accreditors joining international external assessment activities is still limited. The quality standards of education do not meet the regional and international quality standards of education. Meanwhile, the standards for program assessment are being built. Besides, two accrediting agencies have just been established and started their operations. The policy of innovation management and education of the State and Party requires the special assignment of accreditation of education. Law amending and supplementing a number of articles of the Education Act 2009 requires besides accrediting agencies are established by the State must be the involvement establishing accrediting agencies of private organizations and individuals.

Progress of accreditation of higher education in Vietnam is still quite slow compared with the general requirements and not guaranteed stable growth and sustainability. Universities in Vietnam do not pay much attention in accreditation of higher education in general and implementing selfassessment reports in particular because there is a lack of policies relating to the rights of the universities after completing the self-assessment reports or recognized to meet quality standards of education. In addition, in almost universities of Vietnam the awareness of officials, employees and students about accreditation of higher education is not right and adequate. Staff of quality assurance department and implement self-assessment report is not professionally trained. In addition, funding sources for participating accreditation of higher education especially according to the international quality standards of education is very limited.

Therefore, improving accreditation of higher education in Vietnam is an important task for MOET in general and for particular universities in the integration process.

\section{Proposing solutions to Improve Accreditation of Higher Education in Vietnam in the Integration Process}

\subsection{Completing the accreditation system of higher education in Vietnam}

Completing accreditation system of higher education from the national level to the university has important implications for the maintenance of quality standards of education and constantly improves the quality of education in Vietnam in the integration process. For the state, first of all, this system will help to better understand the status of education in the country; while ensuring the rights of learners; ensure that the education system will provide a workforce with the necessary capacity to meet the requirements of the labor market and integration process of country. Accreditation system of higher education will also provide the basis for the state to make effective investment policy for the education system. The learner can know when graduates will have more job opportunities; the results obtained may continue to be higher. The employers feel more secure when recruiting of labor.

Accreditation system of higher education in Vietnam should be completed with the establishment of additional independent accreditation organization with MOET and requires two accrediting centers established at the two National Universities gradually completely independent. 


\section{International Journal of Science and Research (IJSR) \\ ISSN (Online): 2319-7064}

Index Copernicus Value (2013): 6.14 | Impact Factor (2014): 5.611

Besides, the development of quality assurance units of universities which are responsible for the implementing internal quality assurance activities to help universities meet the quality standards of education and implementing selfassessment report as well as monitoring improving continuous improvement.

The development and improvement of accreditation system of higher education in Vietnam includes developing the legal document system of accreditation of higher education. MOET needs to complete the legal document system of implementing of self-assessment, external assessment as well as rules for the operation of accreditation organization of higher education. Moreover, MOET should issue mechanisms for monitoring, controlling operations of accrediting agencies as well as apply encouraged and invested policy to improve efficiency, reputation, brand of accrediting agencies not only domestic but also regional and international.

\subsection{Prescribing the use of result of education accreditation}

The purpose of accreditation of education is not only to ensure responsibility of a university about its quality of training, but also to bring the motivation to improve and enhance the quality of training as well as the quality of the whole university. A result of accreditation is a basis for the accurate assessment of the current situation of university and applying measures to improve quality of education. Besides, a result of accreditation is a motivation for university to strengthen the internal quality assurance and announce publicly to the society. Therefore, the promulgation of the regulations specifies the use of results of accreditation is necessary. MOET should issue regulations on the use of result of accreditation which meets the quality standard of education such as increasing enrollment targets, increasing capital for investment facilities and teaching equipment... Besides, it is necessary to apply sanctions against a university which does not participate in accreditation of education or is underestimated as compared to the quality standard of education.

\subsection{Improving quality standards of education accessing regional and international quality standards}

The organization accreditation usually uses the quality standard of education as a tool for accrediting the educational institutions and programs. The quality standard of education includes requirements and specific conditions of the resources and the implementation process, outcome to confirm to society the quality of education of institution or program.

The quality standards for institutional accreditation in Vietnam was completed while the quality standards for accreditation program is being drafted. The quality standards of higher education in Vietnam need to be improved in order to approach regional and international quality standards such as ABET, AUN-QA... The integration process requires accreditation in many countries tend to gradually recognize mutual results among them. Therefore, the quality standards of higher education of the countries should be similar with each other. The framers of the quality standards of higher education in Vietnam should consult regional and international quality standards and apply the criteria in accordance with the actual quality of higher education in Vietnam today. However, it should be periodically reviewed and the criteria should be gradually improved in order to achieve the regional and international quality standards of education.

\subsection{Strengthening international cooperation in accreditation of higher education}

Accreditation of higher education in Vietnam is a relatively new issue; therefore, learning experiences for implement accreditation of higher education of the countries in the region and the world is very important and necessary. MOET should enhance participation and chair the regional and international workshop about the accreditation of higher education. Besides, enhancing active cooperation with the international accrediting training agencies in training of Vietnamese accreditors to become professional and international accreditors, promoting effective support of foreign experts to participate in the external assessment of higher education accreditation in Vietnam. In addition, strengthening collaboration with international accrediting agencies to implement research projects and to complete accreditation system of higher education in Vietnam to meet the regional and international quality standards. The universities of Vietnam should participate as members of the regional and international accrediting agencies to meet the criteria for accrediting of education according to international quality standards. Moreover, universities in Vietnam should select the advanced training programs and focus on investing accreditation according to international quality standards such as ABET, AUN-QA... to promote quality of training programs. Universities in Vietnam should encourage quality assurance staff search for scholarships, training courses specializing in accreditation and quality assurance of higher education to foster knowledge and raise the professional skills.

\subsection{Strengthening financial resources and investing facilities for accreditation of higher education}

In recent years, accreditation of higher education in Vietnam always receives the attention from MOET and the universities. However, investment in infrastructure and financial resources for the accreditation of higher education is limited. This affects the progress of accreditation of higher education as well as participating in accreditation of education according to the international quality standards. MOET and universities need to invest expenditures for accreditation of education, especially for the training programs accredited according to international quality standards. MOET should issue regulations on the use of funds for accreditation of education as the basis for universities to expense for institutional accreditation and program accreditation. In addition, universities need to invest in infrastructure to serve accreditation of education such as classrooms, libraries, dormitories, laboratories... and the facilities for academic teaching and student services... 


\section{Conclusion}

Quality of education is a vital matter of all countries due to its importance for the quality of human resources - the determinants of the development of the country. Therefore, the quality of higher education has always received the attention of the whole society. The universities always apply measures to improve the quality of education.

Accreditation of education is one of the methods of quality management in education and contributes to improve the quality of education. Most countries in the world deploy accreditation of higher education. Accreditation of higher education in Vietnam in recent years has made significant progress. In the process of integration of the country, the leaders of higher education in Vietnam must apply feasible measures to complete the accreditation system of higher education and legal documents of accreditation system of higher education as well as strengthen international cooperation in accreditation of higher education, enhancing financial resources and investment facilities for accreditation of higher education to meet the regional and international quality standards of education.

\section{References}

[1] Ministry of Education and Training of the Socialist Republic of Vietnam, Regulations of procedures and cycle of accreditation of universities, colleges and professional secondary schools", Hanoi, 2012

[2] Ministry of Education and Training of the Socialist Republic of Vietnam, Regulations of cycle and process of accrediting the curriculum quality of the universities, colleges and professional high schools", Hanoi, 2013

[3] Ministry of Education and Training of the Socialist Republic of Vietnam, -Guidelines for self-assessment of universities, colleges and professional secondary", Hanoi, 2012

[4] Ministry of Education and Training of the Socialist Republic of Vietnam, Eonstruction and project development test system of education quality accreditation for higher education and professional secondary period 2011 to 2020", Hanoi, 2010

[5] Ministry of Education and Training of Vietnam, fnnovation management education system in the period 2010 - 2012”, Hanoi, 2010

[6] Council for Higher Education Accreditation, The Value of Accreditation", Washington DC, 2010

[7] Nguyen Duc Chinh, Accreditation of the quality of higher education", Hanoi National University, Hanoi, 2002

[8] Government of the Socialist Republic of Vietnam, The strategies of Education Development 2011 - 2020", Hanoi, 2012

[9] Grilo, M., - Challenges of education-Ideas for an educational policy in the XXI century (2nd ed.)", Lisbon: Oficina do Livro, 2003

[10]Lazăr VLĂSCEANU, Laura GRÜNBERG, and Dan PÂRLEA, Quality Assurance and Accreditation: A Glossary of Basic Terms and Definitions”, Bucharest, 2007
[11] Morse, J. A., US Regional accreditation abroad: Lessons learned", International higher education, 2008, Retrieved Feb 27, 2009 from http://www.bc.edu/bc_org/avp/soe/cihe/newsletter/Numb er53/p21_Morse.htm

[12] National Assembly of the Socialist Republic of Vietnam, Educational Law", the National Political Publishing House, Hanoi, 2005

[13] National Assembly of the Socialist Republic of Vietnam (2012), Higher Educational Law, Hanoi.

[14] Warren Piper, D., Quality Management in Universities. Canberra: AGPS, 1993

\section{Author Profile}

Nguyen Quang Giao is Vice Director of Department of Higher Education Quality Assurance, The University of Da Nang, Vietnam. $\mathrm{He}$ is a doctor on education management. His research areas are the management of higher education quality. He has performed seven scientific researches and more than 40 scientific papers published in the special journals of the Ministry of education - training and the Da Nang University in 2004 so far as: Journal of Education; Journal of science education; Journal of science - technology of Da Nang University. In addition, many works have been reported in the national and international science education proceedings and workshops. 